\title{
Komitmen Beragama dalam Pendidikan Islam Berbasis Masyarakat Mahasiswa STIT Islamiyah Karya Pembangunan Paron, Ngawi, Jawa Timur
}

\author{
Dian Febrianingsih \\ STIT Islamiyah Karya Pembangunan Paron Ngawi \\ dianfebrianingsih@gmail.com \\ Arih Merdekasari \\ STIT Islamiyah Karya Pembangunan Paron Ngawi \\ arih_atma@yahoo.co.id
}

\begin{abstract}
This study aims to describe and analyze 5 things, 1) factors that influence the religious commitment of students in implementing communitybased Islamic education, 2) forms of community-based Islamic education by students, 3) the impact of community-based Islamic education for students, and 4 ) psychological dynamics of religious commitment of STIT Islamiyah student KP Paron Ngawi in implementing community-based Islamic education. To answer the above problem, the researcher uses qualitative method with case study. Data were collected by in-depth interviews, participatory observation and documentation. The next data is analyzed with Miles \& Hubberman concept which include data reduction, data exposure and conclusion. The form of community-based Islamic education conducted by the students is education diniyah non-formal path that is TPA and / or boarding. Implementation of TPA and pesantren have a positive impact on personal and social life on the whole subject. On the other hand, there is no negative impact of the activity on students. The dimensions of religious commitment consisting of dimensions of belief, ritual, knowledge, experience and belief; have varying degrees of influence on the subjects. Based on this there is a unique dynamics of religious commitment to each subject in the implementation of community-based Islamic education.
\end{abstract}

Keywords: Religious Commitment, College Student, Community-Based Islamic Education

\section{Pendahuluan}

Pendidikan agama memiliki peranan yang penting dalam membentuk akhlak yang baik. Pemahaman yang komprehensif terhadap agama akan mampu membangun moral force yang tangguh dan compatible, sebagai salah satu syarat membangun bangsa yang telah sekian lama dihimpit dan terjerumus dalam kemunduran ${ }^{1}$. Upaya memaksimalkan peran agama dalam kehidupan, melakukan praktik keagamaan yang

${ }^{1}$ Fakhruddin, A.U. "Peran Generasi Muda dalam Keberlangsungan Pendidikan Islam" dalam Insania, Jurnal Pemikiran Alternatif Kependidikan. Vol. 11 No. 2 (Jan-April 2006), 222. Sebagai bahan perbandingan lihat Moh Toriqul Chaer, "Peran Madrasah Dalam Menghadapi Era Globalisasi Dan Budaya," Muaddib:Studi Kependidikan dan Keislaman 6, no. 2 (2016): 183.. 
baik dan tuntas dapat menghadapi perubahan sosial yang semakin pesat, selain itu agama harus dijadikan filter terhadap dampak negatif perubahan sosial. ${ }^{2}$

Individu membutuhkan pengendali atau kontrol dalam berpikir, berperilaku, bertindak yaitu agama atau religiusitas. Religiusitas dapat mempengaruhi setiap aspek kehidupan seseorang secara psikologis dan fisik. ${ }^{3}$ Agama mampu mengendalikan dan mengarahkan penggunaan teknologi untuk kepentingan ummat manusia secara keseluruhan. Dengan panduan agama, teknologi dapat dikembangkan dan diarahkan untuk tujuan-tujuan yang bermanfaat bagi kehidupan, membawa keselamatan dan kebahagiaan ummat manusia. ${ }^{4}$

Berdasarkan data BPS 87.18 \% warga Negara Indonesia beragama Islam. ${ }^{5}$ Secara umum agama Islam merupakan agama yang dianut oleh lebih dari 60\% penduduk pada masing-masing provinsi. Pendidikan Islam berbasis masyarakat dalam hal ini sangat dibutuhkan untuk dilaksanakan dalam menghadapi permasalahan masyarakat yang terjadi. Pendidikan Islam secara luas merupakan dakwah Islam untuk merubah sikap hidup, pengetahuan dan ketrampilan ${ }^{6}$.

Menurut Al Nahlawi pendidikan Islam sebagai pengaturan pribadi dan masyarakat agar dapat memeluk Islam secara keseluruhan ${ }^{7}$. Pendidikan Islam bukan sekedar transfer of knowledge ataupun transfer of training, melainkan lebih merupakan suatu sistem yang ditata di atas pondasi "keimanan" dan "kesalehan" yaitu suatu sistem yang terkait secara langsung dengan Tuhan. ${ }^{8}$

Pendidikan Islam dapat lebih mudah diterima serta dilaksanakan secara mandiri apabila mampu menyesuaikan dengan keadaan masyarakat. Dalam hal ini pendidikan Islam berbasis masyarakat sangat dibutuhkan. Pendidikan berbasis masyarakat

\footnotetext{
2 Ali Amran. "Peranan Agama Dalam Perubahan Sosial Masyarakat" dalam Hikmah Vol II, No. 01 (Januari - Juni 2015), 23. Lihat Chaer, Moh. Toriqul, "542-1568-3-PB.pdf," FENOMENA: Jurnal Penelitian Volume 8, no. No. 1 (2016): 83.

${ }^{3}$ Iredho Fani Reza, "Hubungan Antara Religiusitas Dengan Moralitas Pada Remaja Di Madrasah Aliyah (MA)" Humanitas, Vol X, No. 2 (Agustus 2013). 45

${ }^{4}$ Mohammad Daud Ali. Pendidikan Agama Islam. (Jakarta: PT RajaGrafindo Persada, 2006). 45

5 Badan Pusat Statistik. Kewarganegaraan, suku Bangsa, Agama, dan Bahasa sehari-hari Penduduk Indonesia Hasil Sensus Penduduk 2010. (Jakarta:Badan Pusat Statistik, 2010)

6 Djamaluddin Darwis, Dinamika Pendidikan Islam Sejarah, Ragam dan Kelembagaan, (Semarang: RaSAIL, 2006). 35

${ }^{7}$ Rahman, A. "Pendidikan Agama Islam dan Pendidikan Islam Tinjauan Epistemologi Isi dan Materi” dalam .Jurnal Eksis. Vol. 8 No. 1 (Maret 2012). 2055

${ }^{8}$ Mardia, "Peran Pendidikan Islam Berbasis Kompetensi Dalam Peningkatan Mutu Pendidikan Di PTAI" dalam . Lentera Pendidikan, Vol. 17 No. 2 (Desember 2014). 188
} 
merupakan milik masyarakat secara penuh dan dapat membuat keputusan-keputusan mandiri dalam hal pendanaan, kurikulum dan bentuk pelayanan masyarakat. ${ }^{9}$

Pemuda yang merupakan salah satu unsur masyarakat yang potensial. Pemuda merupakan kelompok strategis yang memiliki vitalitas dalam melakukan perubahan di bidang politik sosial ekonomi dan budaya. ${ }^{10}$ Kalangan muda terpelajar yang sangat diharapkan berperan dalam pendidikan Islam di masyarakat adalah mahasiswa. Peran pemuda sebagai generasi penerus tradisi masa depan, harus belajar dan memahami tradisi, menemani generasi berikutnya dalam proses pemahaman, implementasi dan evaluasi.

Terdapat beberapa alasan mengapa pemuda memiliki tanggung jawab dalam tatanan masyarakat antara lain: kemurnian idealismenya; keberanian dan keterbukaannya dalam menyerap nilai-nilai dan gagasan-gagasan baru; semangat pengabdiannya; spontanitas dan pengabdiannya; inovasi dan kreativitasnya; keinginan untuk segera mewujudkan gagasan-gagasan baru; keteguhan janjinya dan keinginan untuk menampilkan sikap dan kepribadiannya yang mandiri; serta masih langkanya pengalaman-pengalaman yang dapat merelevansikan pendapat, sikap, dan tindakannya dengan kenyataan yang ada. ${ }^{11}$

Keaktifan mahasiswa merupakan salah satu gambaran tentang pengaruh ajaran agama pada perilaku. Khususnya, peran dalam kegiatan pendidikan Islam di masyarakat. Hal itu merupakan bagian dari komitmen beragama, yaitu kesanggupan untuk terikat pada ajaran dan kewajiban-kewajiban yang bertalian terhadap kepercayaan kepada Tuhan dan hubungan moral dengan umat manusia yang diwujudkan dalam bentuk tingkah laku jangka panjang.

Komitmen beragama dibentuk oleh lima dimensi, yaitu ideologis, ritualitas, eksperensial, intelektualitas dan konsekuensial; sudah sering digunakan dalam variabel penelitian yang diteliti dengan variabel lain. Sebagaimana dalam penelitian yang dilakukan oleh Titian Hakiki dan Rudi Cahyono mendeskripsikan komitmen

\footnotetext{
${ }^{9}$ Toto Suharto. Pendidikan Berbasis Masyarakat: Relasi Negara dan Masyarakat dalam Pendidikan, (LKIS Pelangi Aksara, 2015).

${ }^{10}$ Badan Pusat Statistik. Penyajian Data Informasi Kementerian Pemuda dan Olahraga Tahun 2009.(Jakarta: Biro Perencanaan Sekretariat Kementerian Pemuda dan Olahraga, 2009)

${ }^{11}$ Wahyu Ishardino Satries, Peran Serta Pemuda Dalam Pembangunan Masyarakat, Jurnal Madani Edisi I (Mei 2009). 89
} 
beragama pada muallaf (orang yang baru masuk Islam) ${ }^{12}$. Penelitian yang dilakukan oleh Emily dkk (201l) menyatakan bahwa adanya deskripsi komitmen para remaja sebagai bagian dari identitas agama mereka. ${ }^{13}$ Penelitian selanjutnya oleh Joshua dan Laura (2008) menggambarkan bagaimana komitmen beragama dan suasana hati yang positif sebagai informasi tentang makna hidup. ${ }^{14}$

Hasil berbagai penelitian menemukan hubungan yang sangat moderat antara berbagai dimensi dalam komitmen beragama. ${ }^{15}$ Manusia memiliki keberagamaan yang berbeda-beda. Ada yang kuat dalam pelaksanaan sholat (ritualistik) akan tetapi lemah dalam pengetahuan fiqihnya (intelektualitas). Sebaliknya ada orang yang memiliki pengetahuan agama yang baik (intelektualitas) tapi kurang konsisten dalam pelaksanaannya (konsekuensial). Namun ada juga yang yang melakukan ibadah rutin karena pengetahuan agamanya yang baik.

Komitmen beragama memiliki beberapa dimensi yang membentuknya. Teori tentang faktor komitmen beragama pada dasarnya ada tiga. yaitu dikotomi, trikotomi dan multidimensi. Dikotomi menjelaskan dimensi pemaknaan dan kepemilikan, trikotomi menjelaskan dimensi kognitif, afektif dan psikomotorik, sedangkan multidimensi menjelaskan dimensi intelektualitas, pengalaman, ritual, konsekuensial dan kepercayaan ${ }^{16}$. Ditambahkan Kaizawa, untuk memperoleh pemahaman yang lebih lengkap terhadap mekanisme pembentukan komitmen beragama dilakukan kombinasi dua teori, yaitu multidimensi dan trikotomi. ${ }^{17}$

Teori trikotomi komitmen beragama diambil dari taksonomi tujuan belajar Bloom, yaitu kognitif, afektif dan psikomotor.Berdasarkan penelitian terbaru terdapat penambahan aspek intuitif dalam taksonomi tujuan belajar dengan asumsi ketika mempelajari sisi kognitif sebuah perilaku, seseorang juga sedang mempelajari sisi

\footnotetext{
12 Titian Hakiki dan Rudi Cahyono. Komitmen Beragama Pada Muallaf (Studi Kasus Pada Muallaf Usia Dewasa). Jurnal Psikologi Klinis dan Kesehatan Mental. Vol. 4 No. 1 (April 2015). 20

${ }^{13}$ Emily Layton, David C. Dollahite \& Sam A. Hardy. Anchors of Religious Commitment in Adolescents. Journal of Adolescent Research. 26 (3) 2011. 381-413.

${ }^{14}$ Joshua A. Hicks, Laura A. King. Journal of Research In Personality. 42 (2008) 43-57. Religious Commitment And Positive Mood as Information About Meaning In Life.

${ }^{15}$ Rakhmat, J. Psikologi Agama sebuah Pengantar. (Bandung: Mizan, 2013)

${ }^{16}$ Eiko Takamizawa. Religious Commitment: Theory A Model for Japanese Christians. Torch Trinity journal. Vol 2 No 11 (1999) 64-82

${ }^{17}$ Eiko Takamizawa. Religious Commitment: Theory A Model for Japanese Christians. Torch Trinity journal. Vol 2 No 11 (1999) 64-82
} 
afektif, psikomotor dan intuitif ${ }^{18}$. Selanjutnya, Starck dan Glock menjelaskan teori kelima dimensi komitmen beragama sebagai berikut; ${ }^{19}$

1) Dimensi kepercayaan terdiri dari harapan bahwa orang religius akan memiliki pandangan teologis tertentu dan mengakui kebenaran ajaran agama.

2) Praktek keagamaan mencakup tindakan pemujaan dan pengabdian. Praktik keagamaan terbagi dalam dua hal penting: ritual dan pengabdian.

3) Dimensi pengalaman merupakan pengetahuan subjektif dan langsung tentang kenyataan tertinggi.

4) Dimensi pengetahuan mengacu pada pengetahuan tentang ajaran dasar iman, ritus, tulisan suci dan tradisinya.

5) Dimensi konsekuensi mengidentifikasi efek dari kepercayaan, praktik, pengalaman, dan pengetahuan religius dalam kehidupannya sehari-hari.

Berdasarkan dimensi komitmen beragama Glock, Rakhmad menjelaskan lebih lanjut sebagai berikut ${ }^{20}$ :

1) Dimensi ideologis merupakan hal mendasar yang membedakan agama satu dengan agama lainnya. Keyakinan ini terdiri dari; keyakinan dasar, keyakinan tujuan tuhan menciptakan manusia serta keyakinan tentang jalan mencapai tujuan Tuhan dalam menciptakan manusia.

2) Dimensi ritualistik adalah perilaku khusus yang ditetapkan oleh suatu agama, seperti tata cara beribadah dan berpakaian.

3) Dimensi eksperensial adalah dimensi yang berkaitan dengan perasaan individu seperti kekhususkan dan hal mitis yang dialami.

4) Dimensi intelektual adalah informasi khusus yang harus diketaui suatu penganut agama tertentu, dalam Islam disebut sebagai ilmu fikih. Jika seseorang sangat dogmatis akan cenderung menolak tafsir dari golongan selain dirinya.

5) Dimensi konsekuensial adalah efek ajaran agama yang diterapkan seseorang dalam perilaku sehari-hari.

\footnotetext{
${ }^{18}$ Veysel, Sonmez. Associationof Cognitive, affective, Psychomotor and Intuitive domains in education, sonmez Model.Universal Journal of Educational Research 5 (3). (2017) . 347-356

${ }^{19}$ Rodney Stark \& $C$ Clark Y. Glock. American Piety: The Nature of Religious Commitment. (California: University of California Press)

20 Rakhmat, J. Psikologi Agama Sebuah Pengantar. (Bandung: Mizan, 2003)
} 
Seiring dengan banyaknya kajian dan penelitian tentang dimensi komitmen beragama, peneliti tertarik melihat dari sisi fenomenologi. Kanter (1972) membagi komitmen beragama menjadi 3 dimensi yaitu ideational (keyakinan yang dimiliki), communal (kelompok yang diikuti), experiental/ spiritual (pengalaman subyektif). Berdasarkan uraian di atas, terdapat dua dimensi yang sama antara komitmen beragama model dari Stark dan Glock dengan komitmen beragama model Kanter (1972) yaitu dimensi keyakinan dan pengalaman. Sedangkan dimensi yang berbeda adalah dimensi komunal Kanter (1972) yang merupakan bagian dari dimensi konsekuensial Stark dan Glock (1969) yaitu adanya pengaruh agama ketika pemeluknya mengikuti kelompok keagamaan.

Dalam penelitian ini peneliti menggabungkan dua teori untuk lebih memahami komitmen beragama, yaitu taksonomi tujuan belajar Sonmez (2017) dan dimensi komitmen beragama Glock dan Stark. Dimensi komitmen beragama terdiri dari; aspek kognitif (pengetahuan), aspek intuitif (keyakinan), aspek perasaan (pengalaman subyektif), aspek psikomotor (ritual dan konsekuensial).

Perbedaan dinamika dimensi komitmen beragama mahasiswa ditemukan dalam survey awal. Dl mahasiswa semester VI menyatakan bahwa Ia terdorong untuk memenuhi permintaan masyarakat yang membutuhkan tenaga pendidik agama Islam. Hn mahasiswa semester IV menyatakan bahwa kemirisannya melihat perkembangan remaja membuatnya aktif kegiatan mendidik REMAS didesanya. Sedangkan El mahasiswa semester VIII menjelaskan bahwa ajaran agama Islam untuk membina hubungan baik dengan sesama membuatnya aktif melakukan kegiatan keagamaan di masyarakat.

Berdasarkan uraian di atas, komitmen beragama mahasiswa dalam pendidikan agama Islam berbasis masyarakat sangat layak untuk diteliti, karena dengan memahami komitmen beragama mahasiswa dapat memberikan pengetahuan yang mendalam tentang dinamika yang terjadi pada diri mahasiswa dalam melaksanakan pendidikan Islam berbasis masyarakat. Dalam penelitian ini penelitian akan mencoba menganalisis dinamika komitmen beragama mahasiswa dalam melaksanakan pendidikan Islam berbasis masyarakat. 


\section{Pembahasan}

A. Faktor-faktor yang Mempengaruhi Komitmen Beragama Mahasiswa dalam Pendidikan Islam Berbasis Masyarakat

Menurut Worthington dkk komitmen beragama adalah kepatuhan menjalankan ajaran agama dengan cara mengamalkannya di kehidupan nyata ${ }^{21}$. Faktor pembentuk komitmen beragama mencakup faktor internal dan eksternal. Faktor internal dalam komitmen beragama seseorang dibentuk oleh, pengorbanan, dan motivasi beragama seseorang atau disebut sebagai orientasi religius. Orientasi religius bisa dimaknai sebagai tujuan manusia mengamalkan ajaran yang ada dalam sebuah agama.

Orientasi religius terbagi dua yaitu pertama, orientasi religius intrinsik menunjukkan bahwa seseorang mengamalkan ajaran agama karena keyakinannya yang menganggap ajaran agama adalah hal yang mulia dan layak untuk diikuti. Dan kedua, orientasi religius ekstrinsik yang menunjukkan bahwa seseorang mengamalkan ajaran suatu agama karena tujuan tertentu yang terkait dengan pemenuhan kebutuhannya.

Berdasarkan definisi tersebut, hasil wawancara terhadap subjek menunjukkan pentingnya agama bagi subjek sebagai pedoman untuk menjalani sesuai dengan berpedoman pada Al Qur'an dan hadits sebagai bekal ke akherat.

Sikap menjadikan Al Qur'an dan hadits sebagai pedoman hidup sesuai dalam Al Qur'an surat an Nisa (4) ayat 59 yang berarti sebagai berikut, "Hai orang-orang yang beriman, taatilah Allah, taatilah RasulNya dan ulil amri di antara kaти...”22 Bentuk mentaati Allah dan RasulNya yaitu dengan berpegang teguh pada Al Qur'an dan Hadits sebagaimana sabda Nabi sebagai berikut; "Telah menceritakan kepadaku dari Malik bahwasanya dia menyampaikan bahwa Rasulullah saw bersabda: "Aku tinggalkan dua pusaka pada kalian, jika kalian berpegang pada keduanya, niscaya tidak akan tersesat, yaitu kitab Allah (Al Qur'an) dan Sunnah Rasul-Nya." (HR. Malik) $)^{23}$

${ }^{21}$ Worthington, E., Wade, N., Hight, T., Ripley, J., McCullough, M., Berry, J.,Bursley, K., \& O'Connor, L. The Religious Commitment Inventory-10: Development, refinement, and validation of a brief scale for research and counseling. Journal of Counseling Psychology, 50 (1), (2003) 84-96.

${ }^{22}$ Muhammad Daud Ali. Pendidikan Agama Islam. (Jakarta: PT RajaGrafindo Persada, 2006) 91.

${ }^{23}$ Muhammad Daud Ali. Pendidikan Agama Islam. (Jakarta: PT RajaGrafindo Persada, 2006) 93 
Hasil wawancara menunjukkan bahwa para subjek mempunyai prinsip utama dalam Islam yang dijadikan sebagai pedoman utama dalam kehidupan beragama masing-masing. Prinsip utama tersebut adalah memegang teguh syahadat dan Al Qur'an hadits, menjadikan Islam sebagai jiwa sejak dan menerapkan agama Islam sejak usia dini. Kesemua prinsip tersebut diaplikasikan para subjek dengan berbagai cara diantaranya menjalankan perintahNya dan menjauhi larangan-Nya, mengajak orang lain berbuat baik, terus berusaha untuk memperbaiki diri, dan melaksanakan pendidikan Islam di masyarakat.

Dari segi orientasi religius ekstrinsik, hasil wawancara memberikan gambaran bahwa para subyek menganggap agama bisa memenuhi tujuan hidup manusia untuk memenuhi semua kebutuhan yang terkait dengan peribadahan kepada Allah SWT. Hal tersebut senada dengan Maurice Bucaille, $1976^{24}$ yang menyatakan bahwa agama Islam adalah agama yang selalu mendorong manusia untuk mempergunakan akalnya untuk memahami ayat-ayat kauniyah yang terbentang di alam semesta dan memahami ayat-ayat qur'aniyah yang terdapat dalam Al Qur'an mengandung pernyataan ilmiah yang sangat modern.

Orientasi religius intrinsik dianggap memiliki nilai yang lebih baik dari orientasi religius intrinsik. Dalam Islam konsep ini dekat dengan rasa ikhlas. Sedangkan orientasi religius ekstrinsik dekat dengan konsep pamrih dan menginginkan adanya imbalan untuk dapat mencukupi kebutuhannya. Allport dan Rose menegaskan bahwa orang yang memiliki orientasi religius intrinsik hidup dengan agamanya sedangkan orang yng memiliki orientasi religius ekstrinsik hidup menggunakan agamanya ${ }^{25}$.

Orientasi religius intrinsik mencakup hubungan antara dimensi keyakinan dengan konsekuensial. Keyakinan seseorang terhadap ajaran agamanya mengarahkan dirinya untuk melakukan hal yang sesuai di kehidupan nyata. Semua subyek menunjukkan bahwa keyakinan mengarahkan tindakannya aktif dalam kegiatan pendidikan Islam berbasis masyarakat.

\footnotetext{
${ }^{24}$ Muhammad Daud Ali. Pendidikan Agama Islam. (Jakarta: PT RajaGrafindo Persada, 2006) 46

25 Hereck, G.M. Religious orientation and prejudice; A comparison of racial and Sexual Attitudes. Personality and Social Psychology Buletin, 13(1) (1987) 34-44
} 
Hal lain yang berpengaruh bagi komitmen beragama seseorang adalah pengorbanan. Pengorbanan menandakan seseorang bersungguh-sungguh dalam mencapai suatu tujuan. Pengorbanan yang dilakukan penganut agama untuk menjalankan agamanya secara konsisten merupakan salah satu indikator yang menunjukkan kadar keimanannya. Pengorbanan merupakan salah satu konsep penting didalam Islam.

Dari hasil wawancara menunjukkan para subyek melakukan pengorbanan dalam melaksanakan pendidikan Islam di masyarakat. Pengorbanan yang dilakukan subyek baik berkorban dalam waktu, tenaga dan biaya justru menimbulkan perasaan yang sangat dinamis, perasaan yang nikmat, nyaman dan lebih tenang dalam beribadah. Pengorbanan itu dirasakan subyek sebagai wujud komitmen dan bentuk tanggung jawab subyek dalam melaksanakan pendidikan Islam di masyarakat.

Pengorbanan dalam Islam lekat dengan syari'at ibadah qurban yang tercatat sudah ada sejak zaman Nabi Adam dalam QS Al Maidah (5): 27 dengan kisah keturunannya, Qabil dan Habil. Ritual qurban bukan sekedar ritual tanpa makna. Ibadah qurban merupakan penciptaan salah satu hukum Islam yang menjadi tolak ukur ketaqwaan manusia dalam kehidupan kepada Allah SWT. ${ }^{26}$ Hal tersebut senada dengan pendapat pendapat Khan dan Anwar bahwa bahwa konsep pengorbanan yang terdapat dalam Idul adha adalah simbol rasa syukur atas bimbingan yang telah diberikan Allah. ${ }^{27}$

Faktor eksternal komitmen beragama mencakup hubungan dengan keluarga dan teman/ komunitas. Adanya pengalaman, pengorbanan dan orientasi religius seseorang dipengaruhi oleh pendidikan yang diterima. Seseorang menerima pendidikan yang paling dekat dari lingkungan keluarga kemudian kelompok atau teman dan sahabatnya. Nilai-nilai yang diterapkan atau diakui dalam keluarga dan kelompok seseorang sangat berpengaruh dalam membentuk ketiga faktor tersebut. 2016), 80 .

${ }^{26}$ Durrotul Faridah, Metamorfosis Ibadah Kurban Dalam Al Qur'an. Qaf, Vol I No. 01 (September

${ }^{27}$ Khan, M.S dan Anwaar, M. Symbolic Important Of Ritualof Sacrifice On Eid Ul Adha (Research Based Study On Satellite Town Rawalpind). International Journal Of Research In Appliednatural And Social Science (IMPACT:IJRANS)2013, 1(3);59-62 
Dari hasil wawancara, menunjukkan bahwa tidak semua subyek mendapatkan pengaruh dalam pembentukan komitmen beragama dari keluarga. Kurangnya pengetahuan dan tauladan yang diberikan oleh orang tua secara konsisten membuat seorang anak tidak mau mengikuti nilai-nilai yang diterapkan orang tuanya. Keadaan ini membuat anak akan mencari figur lain yang dianggap pengetahuannya lebih baik dan konsisten.

Hubungan antara orang tua dan anak juga cenderung berkonflik karena memiliki pemahaman yang berbeda dalam hal agama. Meniru merupakan salah satu cara belajar yang efektif. Dalam kehidupan terdapat banyak model untuk ditiru dan manusia memiliki kesempatan untuk memilih model yang akan $\operatorname{ditiru}^{28}$

Peran keluarga akan berjalan dengan baik apabila orang tua memiliki ilmu yang mencukupi serta mampu memberikan tauladan yang konsisten. Perbedaan pemahaman agama dari hasil belajar dari sumber yang berbeda akan didiskusikan, masing-masing anggota keluarga akan berusaha memahami sudut pandang satu dengan yang lainnya. Dalam keadaan berkonflik, biasanya akan ada pemecahan masalah dengan penerapan toleransi.

Pendidikan agama Islam dirumah semakin kuat apabila antara anggota keluarga memiliki visi yang sama. Akan ada hubungan yang saling menguatkan ketika ada yang merasa lemah untuk dapat mencapai tujuan tersebut. Keluarga yang menjaga hubungannya biasanya akan lebih terbuka untuk saling belajar dari satu dengan yang lain, mereka juga memiliki komitmen yang kuat untuk menjalankan sebuah kegiatan yang ditujukan untuk beribadah kepada Allah. Sebagaimana pendapat Hurlock (2004) bahwa orang-orang dewasa yang dibesarkan dalam keluarga yang erat beragama cenderung lebih tertarik pada agama daripada yang dibesarkan dalam keluarga yang kurang peduli pada agama.

Faktor eksternal lainnya berasal dari teman dan sahabat. Teman yang memilki visi yang sama, menerapkan sikap saling menghormati dan menghargai akan membuat seseorang lebih mudah introspeksi dan belajar dari pengalaman

${ }^{28}$ Jess Feist \& Gregory J. Feist. Theoriest of Personality. Terj. Yudi Santoso. (Yogyakarta: Pustaka Pelajar, 2008) 
hidup. Dibutuhkan adaptasi agar bisa memahami karakter dan menghargai perbedaan setiap orang sehingga bisa mengendalikan konflik yang terjadi.

Pertemanan yang menguatkan komitmen beragama memiliki indikator sikap berani mengingatkan apabila ada yang salah atau melenceng dari visi yang dimiliki bersama. Dari hasil wawancara kepada subyek, ditemukan hasil bahwa lingkungan teman dan sahabat mempengaruhi pembentukan komitmen beragama subyek. pengaruh tersebut. Temuan di lapangan menunjukkan bahwa teman dan sahabat bisa memperkuat atau memperlemah komitmen beragama subyek dalam melaksanakan pendidikan Islam di masyarakat.

Hal tersebut sebagaimana pendapat Hurlock ${ }^{29}$ bahwa orang dewasa dini lebih memperhatikan hal-hal keagamaan jika tetangga dan teman-temannya aktif dalam organisasi-organisasi keagamaan daripada teman-temannya yang kurang peduli. Subandi menyebutkan di Indonesia perhatian orang muslim terhadap agamanya meningkat secara signifikan sejak tahun 1980. Hal tersebut ditandai dengan meningkatnya antusiasme para muslim muda dalam mengikuti aktifitas religius. Vatikiotis (1990) menemukan rasa kepercayaan diri baru muncul pada umat muslim mayoritas di Indonesia. Sebuah kebangkitan dalam kepercayaan dapat ditemukan pada generasi muda dalam beberapa tahun terakhir. Fenomena tersebut terus berkembang sampai memasuki abad $21 .{ }^{30}$

Berdasarkan analisis di atas, maka dapat diambil kesimpulan secara keseluruhan faktor internal yang mencakup orientasi religius intrinsik, ekstrinsik dan pengorbanan, berperan dalam membentuk komitmen beragama keseluruhan subyek penelitian. Berbeda dengan faktor eksternal, yang menunjukkan hasil yang berbeda. Subyek 1 dan 3, faktor keluarga cukup dominan dalam membentuk komitmen beragama, sedangkan pada subyek 2 dan 4, pengaruh paling kuat justru berasal dari komunitas/ teman.

${ }^{29}$ Elizabeth B Hurlock. Psikologi Perkembangan; Suatu Pendekatan Sepanjang Rentang Kehidupan. Alih bahasa: Istiwidayanti \& Sijabat, Max R. (Jakarta: Erlangga,2004). 280

30 Subandi. Psikologi Dzikir:Studi Fenomenologi Dzikir Tawakkal. Pengalaman Transformasi Religius. (Yogyakarta: Pustaka Pelajar dan Fakultas Psikologi UGM, 2009), 2-3 


\section{B. Pelaksanaan Pendidikan Islam berbasis masyarakat oleh Mahasiswa}

Pendidikan Islam berbasis masyarakat adalah penyelenggaraan pendidikan berdasarkan kekhasan agama sebagai perwujudan dari, oleh dan untuk masyarakat itu sendiri. Dari hasil wawancara, didapatkan temuan bahwa kesemua subyek menunjukkan minat yang tinggi untuk melaksanakan pendidikan Islam di masyarakat.

Hal tersebut karena kesemua subyek tinggal di lingkungan yang mendukung mereka untuk aktif di masyarakat. Sebagaimana pendapat Hurlock bahwa orang-orang dewasa yang tinggal di pedesaan dan di pinggir kota menunjukkan minat yang lebih besar pada agama daripada orang yang tinggal di kota. $^{31}$

Pendidikan Islam berbasis masyarakat yang dilakukan oleh subyek berbentuk pendidikan diniyah nonformal yang berbentuk pendidikan Al Qur'an/ TPA dan juga pesantren. Penyelenggaraan TPA yang dilakukan oleh subyek dipusatkan di masjid, mushalla dan rumah pendiri TPA.

Kurikulum pendidikan TPA yang dilakukan oleh subyek mengacu pada kurikulum pendidikan Al Qur'an sesuai PP No. 55 Tahun 2007 yaitu membaca, menulis dan menghafal ayat-ayat Al Qur'an, tajwid, serta menghafal doa-doa utama. Disamping itu terdapat materi lain yang diberikan yaitu bahasa Arab, sejarah Nabi, Fiqih dan Aqidah-akhlaq.

Temuan di lapangan menunjukkan bahwa kemudahan yang dirasakan subyek dalam mengajar TPA diantaranya adalah pelaksanaan TPA yang kondisional dan peserta TPA yang masih usia anak-anak dengan semangat belajar yang masih tinggi dan masih mudah untuk diarahkan dan dibimbing.

Sedangkan kendala yang dihadapi oleh para subjek adalah kurangnya dukungan dari teman dalam mengajar TPA dan kurangnya fasilitas mengajar baik peralatan mengajar maupun buku pegangan guru. Kendala yang dihadapi oleh subyek diakui kadang bisa melemahkan komitmen beragama subyek dalam melaksanakan pendidikan Islam di masyarakat.

${ }^{31}$ Elizabeth B Hurlock. Psikologi Perkembangan; Suatu Pendekatan Sepanjang Rentang Kehidupan. Alih bahasa: Istiwidayanti \& Sijabat, Max R. (Jakarta: Erlangga,2004). 280 
Dari analisis diatas, dapat diambil kesimpulan bahwa secara keseluruhan subyek ikut aktif dalam pendidikan Islam berbasis masyarakat pada jalur pendidikan diniyah nonformal yaitu TPA/ TPQ dan pesantren dengan peserta kisaran usia 3 - 15 tahun.

C. Dimensi Komitmen Beragama Mahasiswa dalam Pendidikan Islam Berbasis Masyarakat

\section{a. Keyakinan}

Keyakinan tentang kebenaran ajaran Islam menjadikan pemahaman aqidah Islamiyah yang intinya adalah tauhid menjadi lebih kokoh. Aqidah Islamiyah dibangun atas pokok-pokok kepercayaan terhadap enam hal yang lazim disebut sebagai rukun iman seperti tertuang dalam firman Allah SWT dalam QS An Nisa: 136 sebagaimana berikut: "Wahai orang-orang yang beriman, tetaplah beriman kepada Allah dan RasulNya, dan kepada kitab yang diturunkan kepada RasulNya serta kitab Allah yang Allah turunkan sebelumnya. Barang siapa mengingkari Allah, malaikat-malaikatNya, kitab-kitabNya, rasul-rasulNya dan hari kemudian, maka sesungguhnya orang itu telah sesat sejauh-jauhnya" (QS An Nisa[4] : 136). Inti aqidah adalah percaya dan pengakuan terhadap keesaaan Allah yang disebut dengan tauhid merupakan landasan keimanan terhadap keimanan lainnya.

Berdasar hasil wawancara, didapatkan hasil bahwa makna syahadat menurut subyek adalah keyakinan kesaksian bahwa manusia siap dan sanggup untuk menjalankan semua perintah Allah SWT dan menjadikan Nabi Muhammad saw sebagai tuntunan dalam kehidupan sehari-hari. Syahadat memberikan pelajaran nilai seperti kesabaran, kecintaan dan keikhlasan. Subyek mengakui adanya hubungan antara keyakinan dan tujuan penciptaan manusia terhadap keputusan subyek untuk melaksanakan pendidikan Islam di masyarakat baik berbentuk TPA maupun pesantren.

Tujuan penciptaan manusia menurut subyek adalah agar manusia beribadah dan menjadikan manusia sebagai khalifah di muka bumi. Hal 
tersebut senada dengan pendapat Basri ${ }^{32}$ yang menyatakan bahwa jika pendidikan Islam diorientasikan pada misi dan fungsi kehidupan manusia, maka orientasi tersebut lebih bernuansa pada performansi manusia yaitu bagaimana manusia seharusnya berperan/ berkiprah sebagai khalifah dan sekaligus sebagai hamba Allah SWT. Segala bentuk potensi manusia yang dikembangkan dalam proses pendidikan akhirnya harus diarahkan untuk dapat tampil berperan aktif dalam mengembangkan, memajukan dan menata kehidupan manusia dalam rangka berbakti/ beribadah kepada Tuhan. ${ }^{33}$

\section{b. Ritual}

Ritual dalam agama Islam biasa disebut dengan syari'ah. Secara terminologis, menurut Aminuddin (2014) syari'ah berisi aturan atau undang-undang yang diturunkan Allah untuk mengatur hubungan manusia dengan Tuhannya, mengatur hubungan sesama manusia dan hubungan antara manusia dengan alam semesta.

Syariat Islam merupakan jalan hidup yang benar dan dijadikan dasar bagi kehidupan manusia, sebagaimana firman Allah dalam QS Al Maidah [5]: 48. Syariat Islam diturunkan kepada manusia untuk dilaksanakan dalam kehidupan di dunia demi mencapai kebahagiaan yang hakiki di dunia dan akherat. $^{34}$

Menurut Daud Ali, ${ }^{35}$ dalam Islam, syari'at adalam landasan fiqih sedangkan fiqih adalah pemahaman tentang syari'at. Term tentang syariat bisa ditemukan dalam QS Al Jatsiyah (45): 18 sedangkan term fiqih tercantum dalam QS At Taubah (9): 122. Lebih lanjut, Aminuddin berpendapat bahwa syari'ah terbagi atas dua bagian besar yaitu: ${ }^{36} 1$ ) Ibadah mahdhah/ ibadah khash/ ibadah khusus yaitu syahadat, shalat, zakat, puasa dan haji. Ibadah mahdhah bersifat vertikal yaitu hubungan antara manusia

\footnotetext{
${ }^{32}$ Hasan Basri. Filsafat Pendidikan Islam. (Bandung: Pustaka Setia, 2009) 179

${ }^{33}$ Hasan Basri. Filsafat Pendidikan Islam. (Bandung: Pustaka Setia, 2009) 189

${ }^{34}$ Aminuddin dkk.. Pendidikan Agama Islam Untuk Perguruan Tinggi Umum. (Bogor: Ghalia Indonesia, 2014) 14.

${ }^{35}$ Mohammad Daud Ali. Pendidikan Agama Islam. (Jakarta: PT RajaGrafindo Persada, 2006). 75 2014) 87

${ }^{36}$ Aminuddin dkk.. Pendidikan Agama Islam Untuk Perguruan Tinggi Umum. (Bogor: Ghalia Indonesia,
} 
dengan Allah SWT; 2) Ibadah ghairu mahdhah/ ibadah 'aam/ ibadah umum atau disebut dengan muamalah. Ibadah ini bersifat horizontal yaitu hubungan antara manusia dengan sesama makhluk dan alam semesta.

Berdasar definisi tersebut, data hasil wawancara menunjukkan bahwa subyek sudah melakukan syariah berupa ibadah mahdhah dan ibadah ghairu mahdhah. Ibadah mahdhah yang dilakukan subyek diantaranya mengucapkan syahadat, melaksanakan shalat baik fardhu maupun sunnah, melaksanakan puasa Ramadhan dan juga puasa sunnah senin-kamis, serta menunaikan zakat fitrah,

Sedangkan dalam aspek ibadah ghairu mahdhah, subyek mengikuti kegiatan sosial keagamaan di masyarakat diantaranya berpartisipasi dalam kegiatan penyembelihan qurban pada saat idul adha atau membantu penyaluran zakat fitrah.

Dari temuan di lapangan, menunjukkan adanya keterkaitan antara ibadah yang dilakukan subyek dengan kegiatan pendidikan Islam berbasis masyarakat yang dilaksanakan. Melalui kegiatan mengajar agama Islam di TPA/ pesantren, subyek merasakan adanya peningkatan dalam kualitas ibadahnya.

\section{c. Pengalaman}

Rudi Cahyono menyebutkan bahwa sebenarnya pengalaman spiritual adalah pemaknaan dari sesuatu yang dialami. Orang bisa saja mengalami pengalaman yang biasa, tetapi orang tersebut memaknai kejadian tersebut sebagai hal yang luar biasa dan mengilhami dia untuk berpikir, merasakan, dan melakukan sesuatu. ${ }^{37}$ Menurut Maslow menyatakan bahwa pengalaman spiritual merupakan kebutuhan tertinggi seorang manusia.

Berdasar definisi tersebut, data di lapangan menunjukkan bahwa pengalaman yang dialami subyek bersifat individual diantaranya pengalaman belajar di pondok pesantren, pengalaman mendapatkan hukuman masa kecil ketika tidak ikut TPA serta pengalaman melihat kondisi sekitar dengan banyaknya kasus anak perempuan hamil di luar

37 Titian Hakiki dan Rudi Cahyono. Komitmen Beragama Pada Muallaf (Studi Kasus Pada Muallaf Usia Dewasa). Jurnal Psikologi Klinis dan Kesehatan Mental. Vol. 4 No. 1 (April 2015). 20 
nikah Dari pengalaman-pengalaman tersebut, subyek mendapatkan kesan mendalam bagi pribadi masing-masing. Kesan tersebut menjadikan subyek merasa lebih nyaman, tenang, tenteram dan aman. Hal tersebut meningkatkan motivasi subyek untuk berpartisipasi aktif dalam kegiatan TPA/ pesantren di masyarakat.

\section{d. Pengetahuan}

Glock dan Stark (1968) menyebutkan bahwa dimensi pengetahuan berkaitan dengan ekspektasi bahwa seseorang yang beragama akan mengetahui beberapa informasi akan prinsip dasar dari kepercayaan yang mereka anut, tata cara beribadah, pengetahuan akan kitab suci dan tradisi dalam agamanya. Daud Ali (2006: 85) menyatakan bahwa kedudukan ilmu sangat penting dan sentral dalam agama Islam. Quraish Shihab, 1996 dalam Daud Ali (2006) menyatakan bahawa sejak manusia diciptakan, manusia telah mempunyai potensi berilmu dan mengembangkan ilmunya dengan izin Allah SWT.

Kewajiban muslim dalam menuntut ilmu tertuang dalam wahyu pertama yang diterima oleh Nabi Muhammad saw yaitu QS Al Alaq: 1 yang berbunyi: "Bacalah dengan (menyebut) nama Tuhanmu". Perintah ini mewajibkan orang membaca artinya membaca ciptaan (ayat-ayat) Allah termasuk Al Qur'an di dalamnya. Hal ini berarti bahwa pengetahuan harus dicari dan diperoleh karena Allah SWT. ${ }^{38}$

Berdasar definisi tersebut, data pada hasil wawancara menunjukkan bahwa subyek mempelajari dan mendapatkan ilmu tentang agama Islam dari berbagai sumber, diantaranya dari keluarga, sekolah, atau pondok pesantren. Ilmu yang dipelajari oleh subyek meliputi ilmu-ilmu agama Islam seperti aqidah, akhlak, fiqih, Al Qur'an-hadits, sejarah Nabi, sejarah Islam, nahwu, shorof, bahasa Arab, ta'lim muta'allim dan sebagainya.

Menurut subyek, pemahaman terhadap ilmu-ilmu tersebut memberikan pengaruh kepada para subjek menjadi lebih percaya diri dan menerapkan pemahaman akan ilmu-ilmu tersebut dalam melaksanakan pendidikan Islam di masyarakat di TPA/ pesantren.

\footnotetext{
${ }^{38}$ Mohammad Daud Ali. Pendidikan Agama Islam. (Jakarta: PT RajaGrafindo Persada, 2006). 68
} 


\section{e. Konsekuensial}

Glock dan Stark (1968) menyebutkan bahwa dimensi konsekuensi merujuk kepada suatu perilaku tertentu yang muncul karena didasari oleh nilai-nilai yang ada dalam agamanya. Glock dan Stark (1968) menyatakan bahwa komitmen beragama seseorang dapat dilihat dari aktivitas individu terhadap agama yang dianutnya. Berdasar hal tersebut akan muncul bentukbentuk perilaku yang dilakukan oleh individu untuk menunjukkan bahwa dirinya merupakan umat dari suatu agama. ${ }^{39}$

Dimensi konsekuensial pada penelitian ini ditunjukkan dari hasil wawancara dengan adanya keputusan subyek untuk aktif dalam melaksanakan pendidikan Islam berbasis masyarakat di TPA/ pesantren. Perilaku-perilaku subyek sebagai bentuk dari dimensi konsekuensial ditunjukkan subyek dengan menjaga adab di masyarakat, menjaga aurat dalam kehidupan sehari-hari, menjadi contoh bagi santri TPA/ pesantren serta bersemangat dalam mengajar di TPA/ pesantren dengan niat untuk mengamalkan ilmu agama. Sebagaimana pendapat Hurlock bahwa masa dewasa dini adalah masa komitmen. ${ }^{40}$

Keputusan subyek untuk aktif dalam mengajar TPA/ pesantren dengan harapan agar generasi selanjutnya lebih baik dari generasi yang sekarang. Hal tersebut senada dengan Akhdiyat dalam Basri yang menyatakan bahwa salah satu tujuan pendidikan Islam adalah tercapainya anak didik yang memiliki keshalehan spiritual yaitu menjalankan perintah Allah SWT dan Rasulullah saw dengan melaksanakan rukun Islam yang lima dan mengejawantahkannya dalam kehidupan sehari-hari. ${ }^{41}$

Hal tersebut sebagaimana pendapat Hasan Langgulung (1988) bahwa generasi baru harus dididik baik dari aspek mental, spiritual, sosial,

\footnotetext{
${ }^{39}$ Titian Hakiki dan Rudi Cahyono, Jurnal Psikologi Klinis dan Kesehatan Mental,. Komitmen Beragama Pada Muallaf (Studi Kasus pada Muallaf Usia Dewasa). Vol.4 No.l (April 2015)

${ }^{40}$ Elizabeth B Hurlock. Psikologi Perkembangan; Suatu Pendekatan Sepanjang Rentang Kehidupan. Alih bahasa: Istiwidayanti \& Sijabat, Max R. (Jakarta: Erlangga, 2004) 246

${ }^{41}$ Hasan Basri. Filsafat Pendidikan Islam. (Bandung: Pustaka Setia, 2009) 148
} 
intelektual, emosional maupun personal agar proses pendidikan Islam berjalan dengan sempurna. ${ }^{42}$

Dari hasil analisis di atas, dapat diambil kesimpulan bahwa masingmasing dimensi komitmen beragama mempunyai tingkat pengaruh yang berbeda-beda terhadap para subyek. Hal tersebut yang menyebabkan terjadinya dinamika komitmen beragama yang unik pada masing-masing subyek dalam melaksanakan pendidikan Islam berbasis masyarakat.

\section{Dampak Pendidikan Islam Berbasis Masyarakat terhadap Mahasiswa}

Berdasar PP No. 55 Tahun 2007 menyebutkan bahwa salah satu bentuk tanggung jawab dari masyarakat adalah menyelenggarakan pendidikan keagamaan yaitu pendidikan ilmu-ilmu yang bersumber dari ajaran agama. Daud Ali menuliskan bahwa dengan ilmu, kehidupan manusia akan bermutu, dengan agama kehidupan manusia akan lebih bermakna. ${ }^{43}$ Pendidikan keagamaan dalam agama Islam yang dilaksanakan di masyarakat berbentuk pendidikan diniyah pada jalur nonformal berupa pendidikan Al Qur'an, pesantren atau bentuk lain yang sejenis.

Sebagaimana telah disebutkan di atas, bahwa bentuk pendidikan Islam berbasis masyarakat yang dilaksanakan oleh subyek adalah berbentuk TPA/ pesantren. Dari pelaksanaan TPA/ pesantren tersebut memberikan dampak baik terhadap dirinya pribadi maupun lingkungan sosial.

Dari hasil wawancara menunjukkan bahwa dengan mengajar di TPA/ pesantren memberikan dampak positif bagi subyek terhadap dirinya sendiri. Dampak positif yang dirasakan subyek dalam aspek pribadinya adalah bahwa subyek berusaha lebih baik dalam membaca Al Qur'an, dalam mengamalkan ibadah-ibadah yang lain, bisa belajar tentang kesabaran, keikhlasan; memperkuat mental ketika didepan santri TPA serta menjadikan subyek lebih berhati-hati ketika bertindak/ berperilaku di masyarakat. Dampak positif lainnya adalaah subyek mendapatkan pengalaman mengajarkan ilmu agama, membuat hidup subyek terasa lebih bermakna serta melatih kedisiplinan.

\footnotetext{
${ }^{42}$ Djamaluddin Darwis. Dinamika Pendidikan Islam: Sejarah, Ragam dan Kelembagaan. (Semarang: RaSAIL, 2006) 68

${ }^{43}$ Mohammad Daud Ali. Pendidikan Agama Islam. (Jakarta: PT RajaGrafindo Persada, 2006). 75
} 
Selain dampak positif, temuan di lapangan menunjukkan bahwa subyek merasa mendapatkan dampak negatif dalam mengajar di TPA/ pesantren. Dampak negatif yang dirasakan subyek terhadap dirinya sendiri diantaranya adalah kurang bisa mengendalikan diri dan mengontrol emosi ketika menghadapi santri TPA yang berperilaku kurang baik didepan subyek serta merasa terbebani dengan kegiatan di luar kegiatan TPA/ pesantren.

Selain terhadap kehidupan pribadinya, ditemukan adanya dampak mengajar TPA/ pesantren bagi subyek terhadap kehidupan sosialnya. Dalam kehidupan sosial, dampak positif yang dirasakan subyek diantaranya yaitu subyek bisa lebih akrab dalam menjalin silaturrahmi dengan lingkungan sekitar. Selain itu subyek merasa dipandang menjadi lebih bisa dan menjadi tempat tumpun di masyarakat.

Bagi santri TPA/ pesantren, adanya TPA/ pesantren yang diselenggarakan berdampak positif bagi mereka seperti menambah pengetahuan dan nilai-nilai agama serta mau menghidupkan suasana keagamaan di rumah masing-masing. Hasil penelitian tidak menunjukkan adanya dampak negatif dari mengajar TPA/ pesantren terhadap kehidupan sosial para subyek. Hasil tersebut senada dengan pendapat Solikdin (2013) yang menyebutkan bahwa pendidikan Islam berperan sebagai pondasi utama dan berperan dalam pendidikan moral bagi pembangunan masyarakat Indonesia seluruhnya. ${ }^{44}$

Selain itu, menurut Ramli (2015) agama mempunyai peranan besar dalam kehidupan manusia, sehingga pantaslah jika terus bertahan dan dipertahankan. Hal tersebut dikarenakan agama mempunyai fungsi yang nyata, tidak hanya sekedar sebagai aturan kehidupan, namun juga memegang peranan yang bersifat universal. ${ }^{45}$

Berdasar analisis di atas, dapat diambil kesimpulan bahwa pelaksanaan pendidikan Islam berbasis masyarakat pada umumnya memberikan dampak positif bagi subyek, baik dalam kehidupan pribadi maupun dalam kehidupan sosial. Tidak ditemukannya dampak negatif yang berarti terhadap para subyek

\footnotetext{
${ }^{44}$ Solikodin Djaelani. Peran Pendidikan Agama Islam dalam Keluarga Dan Masyarakat. Jurnal Ilmiah Widya. Volume I Nomor 2 (Juli-Agustus 2013)

${ }^{45}$ Ramli. Agama dan Manusia. Jurnal Pendidikan Ilmu-ilmu Sosial 7 (2) (2015): 138-144
} 
sehingga hal tersebut menjadikan subyek terus berkomitmen dalam melaksanakan pendidikan Islam berbasis masyarakat.

E. Dinamika Komitmen Beragama Mahasiswa dalam Pendidikan Islam Berbasis Masyarakat

Ancok dan Nashori menyebutkan bahwa dalam psikologi islami ada lima macam dimensi keagamaan yaitu dimensi keyakinan (ideologis), dimensi peribadatan atau praktek keagamaan (ritualistic), dimensi penghayatan (eksperiensial), dimensi pengamalan (konsekuensial) dan dimensi pengetahuan agama (intelektual). ${ }^{46}$ Lebih lanjut disebutkan, konsekuensi komitmen agama berlainan dari keempat dimensi yang sudah dibicarakan. Dimensi ini mengacu pada identifikasi akibat-akibat keyakinan keagamaan praktik, pengalaman dan pengetahuan seseorang sehari-hari. Komitmen beragama bersifat multidimensional dimensi-dimensi yang ada didalamnya memiliki pola hubungan yang unik.

Dari hasil analisis yang dilakukan, ditemukan adanya dinamika komitmen beragama yang unik pada masing-masing subyek. Pada mereka ditemukan perbedaan dinamika komitmen beragama yang mempengaruhi subyek dalam melaksanakan pendidikan Islam berbasis masyarakat.

Pada subyek 1 terjadi dinamika yang menggambarkan bahwa dimensi pengetahuan menumbuhkan dimensi keyakinan dalam melaksanakan ritual agama sehingga subyek 1 mendapatkan pengalaman spiritual. Dari pengalaman yang didapat, menjadikan subyek 1 merasa yakin untuk terus melaksanakan pendidikan Islam berbasis masyarakat sebagai bentuk dimensi konsekuensial.

Keaktifan subyek dalam pelaksanaan pendidikan Islam berbasis masyarakat membuat subyek terus belajar untuk mendapatkan pengetahuan agama. Dari kelima dimensi, bisa disimpulkan bahwa bagi subyek 1 dimensi pengetahuan memegang peranan yang paling tinggi dalam pelaksanaan pendidikan Islam berbasis masyarakat.

${ }^{46}$ Djamaluddin Ancok \& Fuad Nashori Abdullah.. Psikologi Islam. (Yogyakarta: Pustaka Pelajar, 
Berbeda dengan subyek 2. Gambaran dinamika komitmen beragama subyek 2 menunjukkan bahwa kelima dimensi tersebut saling mempengaruhi dalam keaktifannya melaksanana pendidikan Islam berbasis mayarakat. Bisa disimpulkan bahwa tidak ada dimensi dominan yang mempengaruhi subyek 2 dalam melaksanakan pendidikan Islam berbasis masyarakat.

Bagi subyek 3, dimensi yang paling mempengaruhinya dalam melaksanakan pendidikan Islam berbasis masyarakat adalah pengetahuan dan pengalaman sebagai wujud dimensi konsekuensial. dimensi ritual yang dijalankan subyek menumbuhkan keyakinan bahwa ketika manusia menjalankan apa yang menjadi perintah agama, maka keyakinan akan datangnya pertolongan Allah pasti ada. Lain halnya dengan subyek 4, dimensi yang paling tinggi pengaruhnya dalam melaksanakan pendidikan Islam berbasis masyarakat adalah dimensi pengalaman dan keyakinan. Dimensi pengetahuan agama yang didapatnya hanya dari sekolah membuat ritual agama subyek 1 berjalan sesuai kebutuhannya.

Dinamika komitmen beragama yang didapati dalam penelitian ini, menunjukkan bahwa tingkat kesalehan ritual seseorang belum tentu berbanding lurus dengan kesalehan sosial. Mengutip pendapat Rakhmat (2013) yang menyebutkan bahwa yang memilki pengetahuan agama yang tinggi, menjalankan sholat dengan teratur, memiliki keykinan yang kuat, berakhlak baik dalam kehidupan sehari-hari dan sering menangis dalam doanya. Sedangkan yang lain memiliki pengetahuan yang tinggi, menjalankan sholat dengan rutin tetapi melakukan korupsi besar-besaran ${ }^{47}$.

\section{Catatan Akhir}

Komitmen beragama merupakan bentuk kepatuhan seseorang terhadap nilainilai yang diyakini, dengan mempraktikkannya secara interpersonal dan intrapersonal dalam kehidupan sehari-hari. Faktor pembentuk komitmen beragama terdiri dari faktor internal yang mencakup orientasi religius intrinsik, orientasi religius ektrinsik dan pengorbanan; serta faktor eksternal yang mencakup keluarga dan teman/ komunitas.

\footnotetext{
${ }^{47}$ Rakhmat, J. 2013. Psikologi Agama sebuah Pengantar. (Bandung: Mizan; 40
} 
Secara keseluruhan faktor internal yang mencakup orientasi religius intrinsik, ekstrinsik dan pengorbanan, berperan dalam membentuk komitmen beragama keseluruhan subyek penelitian. Berbeda dengan faktor eksternal, yang menunjukkan hasil yang berbeda. Subyek 1 dan 3, faktor keluarga cukup dominan dalam membentuk komitmen beragama, sedangkan pada subyek 2 dan 4, pengaruh paling kuat justru berasal dari komunitas/ teman.

Terdapat dinamika komitmen beragama yang unik pada masing-masing subyek dalam pelaksanaan pendidikan Islam berbasis masyarakat oleh mahassiwa. Bagi subyek 1 dimensi pengetahuan mempunyai pengaruh yang tinggi, sedangkan bagi subyek 2 tidak ada dimensi yang dominan. Bagi subyek 3, dimensi pengetahuan dan pengalaman yang dominan mempengaruhinya dalam pelaksanaan pendidikan Islam berbasis masyarakat, berbeda dengan subyek 4 yang dominan dipengaruhi oleh dimensi pengalaman dan keyakinan.

Pelaksanaan pendidikan Islam berbasis masyarakat oleh mahasiswa STIT Islamiyah KP Paron tahun akademik 2016/2017 berbentuk pendidikan diniyah jalur nonformal yaitu TPA dan/ atau pesantren. Pendidikan Islam berbasis masyarakat tersebut berdampak positif pada kehidupan pribadi dan sosial masing-masing subyek. Tidak ditemukannya dampak negatif dari pelaksanaan pendidikan Islam berbasis masyarakat terhadap mahasiswa.

\section{Daftar Rujukan}

A.Hicks, Joshua \& A. King, Laura. Religious Commitmenr And Positive Mood as Information About Meaning Of Life. Journal of Research In Personality. 42. 2008

Amran, Ali. Peranan Agama Dalam Perubahan Sosial Masyarakat. Hikmah Vol. II, No. 01 Januari - Juni 2015

Ali, Mohammad Daud. 2006. Pendidikan Agama Islam. Jakarta: PT RajaGrafindo Persada Aminuddin dkk. 2014. Pendidikan Agama Islam Untuk Perguruan Tinggi Umum. Bogor: Ghalia Indonesia.

Ancok, Djamaluddin Ancok \& Abdullah, Fuad Nashori Psikologi Islam. (Yogyakarta: Pustaka Pelajar, 2008)

Badan Pusat Statistik. 2009. Penyajian Data Informasi Kementrian Pemuda dan Olahraga Tahun 2009. Jakarta: Biro Perencanaan Sekretariat Kementerian Pemuda dan Olahraga

Badan Pusat Statistik. 2010. Kewarganegaraan, Suku Bangsa, Agama, dan Bahasa sehari-hari Penduduk Indonesia Hasil Sensus Penduduk 2010. Jakarta:Badan Pusat Statistik

Basri, Hasan. 2009. Filsafat Pendidikan Islam. Bandung: Pustaka Setia

Chaer, Moh. Toriqul. “542-1568-3-PB.Pdf.” FENOMENA: Jurnal Penelitian Volume 8, No. No. 1 (2016): 91-100. 
Chaer, Moh Toriqul. "Peran Madrasah Dalam Menghadapi Era Globalisasi Dan Budaya." Muaddib: Studi Kependidikan dan Keislaman 6, no. 2 (2016): 182-201.

Darwis, Djamaluddin. 2006. Dinamika Pendidikan Islam; Sejarah, Ragam dan Kelembagaan. Semarang: Rasail.

Fani Reza, Iredho. Hubungan Antara Religiusitas Dengan Moralitas Pada Remaja Madrasah Aliyah (MA). Humanitas. Vol. X. No. 02 Agustus 2013

Faridah, Durrotul, Metamorfosis Ibadah Kurban Dalam Al Qur'an. Qaf, Vol I No. 01 (September 2016)

Ishardino Satries, Wahyu. Peran Serta Pemuda Dalam Pembangunan Masyarakat. Jurnal Madani. Edisi I/ Mei 2009

Fakhruddin, A.U. 2006. Peran Generasi Muda dalam Keberlangsungan Pendidikan Islam. Jurnal Pemikiran Alternatif Kependidikan. Vol. 11 No. 2 Jan-April 2006

Hakiki, Titian \& Cahyono, Rudi. Komitmen Beragama Pada Muallaf (Studi Kasus Pada Muallaf Usia Dewasa. Jurnal Psikologi Klinis dan Kesehatan Mental. Vol.4 No. 1 April 2015.

Hereck, G.M. Religious orientation and prejudice; A comparison of racial and Sexual Attitudes. Personality and Social Psychology Buletin, 13(1) (1987).

Hurlock, E, B. Psikologi Perkembangan; Suatu Pendekatan Sepanjang Rentang Kehidupan. Alih bahasa: Istiwidayanti \& Sijabat, Max R. Jakarta: Penerbit Erlangga, 2004

Jess Feist \& Gregory J. Feist. 2008. Theoriest of Personality. Terj. Yudi Santoso. Yogyakarta: Pustaka Pelajar

Khan, M.S dan Anwaar, M. Symbolic Important Of Ritualof Sacrifice On Eid Ul Adha (Research Based Study On Satellite Town Rawalpind). International Journal of Research In Appliednatural And Social Science (IMPACT:IJRANS)2013, 1(3)

Layton, Emily, C. Dollahite, David \& A. Hardy, Sam. Anchors of Religious Commitment in Adolescents. Journal of Adolescent Research (3) 2011

Mardia. Peran Pendidikan Islam Berbasis Kompetensi Dalam Peningkatan Mutu Pendidikan Di PTAI. Lentera Pendidikan. Vol. 17 No. 2 Desember 2014

Rahman, A. 2012. Pendidikan Agama Islam dan Pendidikan Islam Tinjauan Epistemologi Isi dan Materi. Jurnal Eksis. Vol. 8 No. 1 Maret 2012

Rakhmat, J. 2013. Psikologi Agama sebuah Pengantar. Bandung: Mizan

Stark, Rodney Stark \& Glock, Y Clark. American Piety: The Nature of Religious Commitment.California: University of California Press

Subandi. Psikologi Dzikir: Studi Fenomenologi Pengalaman Transformasi Religius. (Yogyakarta: Pustaka Pelajar, 2009)

Suharto, Toto. 2015. Pendidikan Berbasis Masyarakat: Relasi Negara dan Masyarakat dalam Pendidikan. LKIS Pelangi Aksara

Takamizawa, Eiko. 1999. Religious Commitment: Theory A Model for Japanese Christians. Torch Trinity Journal. Vol 2 No 1164-82

Veysel, Sonmez. 2017. Associationof Cognitive, Affective, Psychomotor and Intuitive Domains in Education, Sonmez Model. Universal Journal of Educational Research 5 (3):347-356

Worthington, E., Wade, N., Hight, T., Ripley, J., McCullough, M., Berry,J., Bursley, K., \& O'Connor, L. (2003). The Religious Commitment Inventory 10: Development, refinement, and validation of a brief scale for research and counseling. Journal of Counseling Psychology, 50 (1), 84-96 


\section{Website}

www.nasional.kompas.com "Bintang Mesum" Ngawi Digelandang Polisi. 2008. (online) www.cnnindonesia.com Ratnasari, D.E. Cyber Crime, Kasus Kejahatan Terbanyak di 2016.

www.siaganngawi.com Gaya Hidup Pelajar Ngawi Disoroti FPG.

www.siagangawi.com Delapan Bulan Menjadi Buron, Pembacok Tiga Remaja Pitu Akhirnya Menyerahkan Diri.

www.kominfo.jatimprov.go.id Kontras: Ujaran Kebencian Penyebab Terjadinya Radikalisme 